\title{
GRAMMATICALIZATION OF NOUNS IN JORDANIAN ARABIC: EVIDENCE FROM JIKIL AND OMIR
}

\author{
Murad AL KAYED \\ Al-Balqa Applied University, Jordan \\ E-mail: murad.alkayed@bau.edu.jo
}

\begin{abstract}
The current study aims at exploring the grammaticalization of the nouns fikil 'shape' and omir 'age' in Jordanian Arabic. The data were collected from Jordanian T.V. series and interviews with native speakers of Jordanian Arabic. The sample of the study consisted of 300 tokens of fikil and 200 tokens of omir. The researcher collected the data, then he analysed the functions of these two words. The study found out that fikil was used 100 times as a noun meaning 'shape', and 200 times as an evidential particle. Besides, omir was also used as a noun 60 times and 140 times as a negative polarity item. The findings of the study showed that fikil has one lexical meaning 'shape', and it evolved by the process of grammaticalization into an evidential particle. fikil underwent the process of semantic bleaching, since it lost its content meaning and developed to serve a grammatical function of evidentially. Bedsides, it was decategorized as it lost the grammatical features of nouns, i.e. it cannot be pluralized and cannot accept definite articles. Also fikil lost its stress as part of phonetic reduction. Similarly, omir has one lexical meaning 'age' and developed into a negative polarity item. Omir was affected by the process of semantic bleaching and decategorization as it was developed from its original meaning as a noun meaning 'age' into a negative polarity item. Additionally, omir underwent the process of phonetic reduction as it lost stress. The study found out that $/ i k i l$ and omir underwent three stages of grammaticalization: semantic bleaching, decategorization, and phonetic reduction.
\end{abstract}

KEYWORDS: grammaticalization; fikil; omir; bleaching; decategorization; phonetic reduction, nouns

\section{Introduction}

Grammaticalization refers to "the change whereby lexical items and constructions come in certain linguistic contexts to serve grammatical functions, and, once grammaticalized, continue to develop new grammatical functions" (Hopper \& Traugott, 2003, p.1). In other words, lexical words change over time to indicate the grammatical function. Another definition was provided by Heine and Reh (1984, p.15), who defined grammaticalization "as an evolution whereby linguistic units lose in semantic complexity, pragmatic significance, syntactic freedom, and phonetic substance, respectively". Thus, through the process of grammaticalization, lexical words lose some of their grammatical, phonetic, and pragmatic features. Many linguists, such as Hopper and Traugott (2003) and Heine (2003) believed that this process does not occur at once, but it goes through a chain or a cline. Hopper and Traugott's famous pattern for the cline of grammaticalization illustrates the various stages of the form:

Content word $\rightarrow$ grammatical word $\rightarrow$ clitic $\rightarrow$ inflectional affix

According to this cline, the content word shifts gradually to a grammatical word that may evolve into an affix (Hopper and Traugott, 2003, p. 7). One example of grammaticalization is the English verb "go" which developed from a lexical verb indicating a motion (e.g. Ali goes to the university) to an auxiliary expressing futurity (e.g. "he is going to see a movie tonight"). Grammaticalization of lexical items undergoes four strategies: bleaching, extension, decategorization, and phonological reduction (Hopper and Traugott, 2003). The first stage is semantic bleaching or desemanticization which refers to the process by which the content word loses its original semantic meaning. So the content word shifts it's meaning from lexical to a grammatical meaning (Heine, Claudi \& Hünnemeyer 1991, and Hopper \& Traugott, 1993, p. 88). In this process, the content word gains a very general meaning, as suggested by John Haiman (1991). $\mathrm{He}$ indicates that "semantic reduction, or bleaching, occurs as a morpheme loses its intention: From describing a narrow set of ideas, it comes to describe an ever broader range of them, and eventually may lose its meaning altogether" (Haiman, 1991, p. 154). For example, the lexical verb "go" undergoes the process of bleaching since it loses its original meaning of motion and grammaticalized as a future marker (Hopper and Traugott, 2003).

The second stage is extension, which refers to the process by which the lexical items extend their meaning to be used in new contexts where it could not be used previously. The third stage is decategorization: which refers to the loss of morphosyntactic features of a grammaticalized word. 
According to Bybee (2003, p. 4) decategorization "is applied to the set of processes by which a noun or verb loses its morphosyntactic properties in the process of becoming a grammatical element" (Bybee, 2003, p. 4). For example, when verbs are grammaticalized as auxiliaries, they lose the argument structure. The last stage is phonological reduction, which refers to the process by which the grammaticalized word undergoes phonetic reduction. For example, the English word "will" lost its original meaning of "desire" to indicate a future marker. At the last stage, this word is reduced to "'ll "as in "we'll". Grammaticalization is a universal process in all languages. Thus, the present study aims to investigate the grammaticalization of two nouns in Jordanian Arabic/shikik/'shape' and /omir/'age'. It explores how these words undergo different stages of grammaticalization.

\section{Literature review}

A large body of literature investigated the grammaticalization of lexical items to indicate a grammatical function in different languages (Heine \& Reh, 1984; Traugott \& Heine, 1991; Lehmann, 1995; Bybee, Pagliuca, and Perkins, 1991; Heine and Narrog, 2011; Traugott and Dasher, 2002; Traugott and Trousdale, 2010).

In the Arabic context, many studies examined the phenomenon of grammaticalization; for example, Jarad (2017) investigated the grammaticalization of some lexical words in Emirati Arabic and how they change in form and function. The data were collected from different sources: interviews and personal communication with native speakers of Emirati Arabic, fieldwork, and television series. The study found out that the verb abgi (want) developed to serve future marker and reduced to a prefix $/ \mathrm{ba} /$. Moreover, the lexical meaning (day, time), yōm also underwent grammaticalization, and it is used as subordinate conjunction introducing time clauses. The noun /rūh / (soul) also developed into a reflexive pronoun in Emirati Arabic. The lexical words /hagg/ (right, property) and /māl/ (wealth) developed to serve possessive function. In another study, Jarad (2015) examined the grammaticalization of the active posture participle "yālis" (sitting) in Emirati Arabic. He suggested that "yālis" (sitting) plus imperfective verb developed into an auxiliary marking the progressive aspect in Emirati Arabic. He found out that "yālis" (sitting) undergoes three stages of grammaticalization: desemanticization, extension, and decategorialization. However, this construction kept its phonetic form.

Jarad (2014) investigated the development of the motion verb /rah/ "go" from classical Arabic to a prospective future prefix /b/ in Syrian Arabic. The article found out that the verb/rah/ undergoes all stages of grammaticalization: semantic bleaching (desemanticization), morphosyntactic shift (decategorialization), phonetic shift (erosion), and phonological reduction (cliticization).

Alotaibi (2016) investigated the grammaticalization of the posture verbs /gaam/ 'get up' and /gaYad/ 'sit' in Kuwaiti Arabic. The study proposed that in addition to the lexical meaning of the verb /gaam/ 'get up' in Kuwaiti Arabic, it also serves as an inceptive aspect. The verb /gaSad/ 'sit' also is used to mark a continuous/progressive aspect. Al-Najjar (1991) examined the grammaticalization of the lexical verb Pabi 'I want' in Kuwaiti Arabic. He suggested that the lexical verb Pabi 'I want' developed to a future marker /b/. He noticed that both the lexical verb Pabi, which expresses desire, and the reduced future marker $/ \mathrm{b} /$ are still used in Kuwaiti Arabic.

Eifan (2017) examined the phenomenon of grammaticalization in Urban Hijazi Arabic (a Saudi dialect) by adopting a synchronic and diachronic approach. The study collected the data using a dialectal Arabic questionnaire. The study found out that many words (verbs, nouns, and prepositions) evolved to serve grammatical functions. For example, the preposition maS 'with' developed a grammatical function indicating possession in addition to its basic propositional meaning. Camilleri \& Sadler (2017) discussed the grammaticalization found in contemporary Arabic vernaculars. The study suggested that the posture verb /qaad/ "sitting" developed to indicate an aspectual marker (progressive aspect). This process was found across many dialects of vernacular Arabic.

Woidich (1995) studies the grammaticalization of some words in Egyptian Arabic. He argued that many linguistic items in Egyptian Arabic go through grammaticalization processes such as decategorization, phonetic reduction, semantic bleaching, autonomy, and reanalysis. For example, the adjective /Rahsan/ "better" developed into an adverb meaning "because", then it evolved to the conjunction. 
In the Jordanian Arabic context, Alshboul, Alshboul \& Asassfeh (2010) examined how some lexical words developed to serve future markers in Jordanian Arabic. The study proposed that the lexical word bad(di) evolved into the future marker b(a)-. Similarly, the lexical word /ra(a)Ha/ "went" and /rayih/ "to go" underwent grammaticalization process and developed to the future prefix /Ha-/. The study suggested that the lexical word /Hatta-/ "to+ future form" evolved to /ta-/ "to+ future form". In another study, Al-Shawashreh, et al. (2020) examined the grammaticalization of the verb /gaal/ in the Jordanian Arabic dialect of Irbid (JADI). The study suggests that this verb developed from a lexical verb used to introduce speech into an epistemic verb, an evidentiality verb, and an incredulity marker. As an incredulity marker, the verb gaal undergoes three processes of grammaticalization: semantic bleaching, phonological reduction, and de-categorization.

As it is clear from the previous studies, grammaticalization is an under-researched topic in the Jordanian Arabic context. Besides, the researcher did not find any research that examined the grammaticalization of Jikil "shape" and omir "age" in the Arabic dialects. Thus, the present study aims to fill this gap by investigating the grammaticalization of $/ i k i l$ "shape" and omir "age" to serve as an evidential particle and a negative polarity item, respectively.

\section{Methods}

The data for the present study were collected from Jordanian T.V. series, and interviews with native speakers of Jordanian Arabic. The researcher is a native speaker of Jordanian Arabic, and he can explore the uses of fikil and omir in Jordanian Arabic based on his intuitions. However, he uses interviews and T.V. series to gather a large amount of data, which enables him to reach for frequencies. The participants in the interviews were 48 participants living in Amman (the capital of Jordan) who belong to different social backgrounds (see table 1). The researcher asked the participants different questions about various topics that interest them, such as coronavirus, politics, religion, divorce, marriage, memories, economy, education, war, etc. The researcher recorded these interviews and asked the permission of the participants to use these recordings in the research.

Table 1: The distribution of speakers according to their age and gender

\begin{tabular}{|l|l|l|l|}
\hline & Male & Female & Total \\
\hline Young & 12 & 12 & 24 \\
\hline Old & 12 & 12 & 24 \\
\hline total & 24 & 24 & 48 \\
\hline
\end{tabular}

The data were also collected from the Jordanian Comedy series Jaltah 'stroke' part 1 and 2, which was broadcasted in 2018 and 2019. The total number of episodes that were selected were 50. The researcher extracted the occurrences of $/ \mathrm{ikil}$ and omir, transcribed them using IPA phonetic transcription, and analyzed them with respect to their functions. The distribution of $/ i k i l$ and omir in the data were represented in Table $2 \& 3$ :

Table 2. Distribution of $/ i k i l$ in the data

\begin{tabular}{|c|c|c|c|}
\hline & \multicolumn{1}{|c|}{ A noun meaning } & An Evidential & total \\
\hline 'shape.' & Particle & 300 \\
\hline fikil & 100 & 200 & $100 \%$ \\
\hline
\end{tabular}

Table 3. Distribution of omir in the data

\begin{tabular}{|c|c|c|c|}
\hline & 'age' A noun meaning of & $\begin{array}{lll}\text { A Negative polarity } \\
\text { item }\end{array}$ & total \\
\hline omir & 60 & 140 & 200 \\
\hline$\%$ & $30 \%$ & $70 \%$ & $100 \%$ \\
\hline
\end{tabular}


As shown in table $2 \& 3$, fikil was used 100 times as a noun meaning 'shape', and 200 times as an evidential particle. Besides, Omir was also used as a noun 60 times and 140 times as a negative polarity item.

\section{Results and discussion}

The results of the study showed that fikil in Jordanian Arabic has one primary content meaning 'shape' and it was used 100 times (33.3\%) in the corpus. It was used as an evidential particle 200 times $(66.7 \%)$. The findings revealed that omir has one basic lexical meaning 'age' used 60 times (30\%) and it developed into a negative polarity item used 140 times (70\%).

\section{1. $\quad$ Noun $>$ evidentiality particle}

The noun fikil in Jordanian Arabic has a lexical meaning of "shape" or "format", as shown in the following examples:

$$
\begin{aligned}
& \text { Ma: baSrif jikil-uh } \\
& \text { NEG. know } 1 \text { S.G. shape-GEN.M } \\
& \text { 'I do not know his shape' } \\
& \text { Sajab-ni: Jikil al-fajdzarah } \\
& \text { Like. past-I shape ART-tree } \\
& \text { I liked the shape of the tree } \\
& \text { fikil-uh muxi:f } \\
& \text { Shape-3SG.M scary } \\
& \text { 'He looks scary' }
\end{aligned}
$$

As shown in the previous examples, fikil has a content meaning of shape. The content word fikil "shape" undergoes semantic bleaching in Jordanian Arabic and evolves to indicate a grammatical meaning of "evidentially". Both uses of fikil as a lexical item and an evidential particle were used in Jordanian Arabic. Evidentiality is a grammatical category whose primary meaning is the source of information (Aikhenvald, 2004: 3) whether the speaker gets it directly by seeing the event described or indirectly by being told about the event, or creating inferences based on some information. Boas (1938, p. 133) proposed that "while for us definiteness, number, and time are obligatory aspects, we find in another language location near the speaker or somewhere else, source of information - whether seen, heard, or inferred - as obligatory aspects." Jarrah \& Alshamari (2017) indicated in their study that the word Jikil is used in Jordanian Arabic as an evidential particle to express indirect evidentiality. The particle fikil expresses the speaker's dependence on indirect evidence, such as third party reports, inferences, and background and experiential knowledge, etc., as the source of information. Consider the following examples:

$$
\begin{array}{cll}
\text { Sikil-ak kasart } \quad \text { Ji: } & \multicolumn{1}{c}{\text { bi-l-mat'bax }} \\
\text { Shape-you break. Past } & \text { something } & \text { in-ART-kitchen } \\
\text { 'Evidentially, you broke something in the kitchen.' }
\end{array}
$$

In this example, the speaker depends on his experiences (i.e., hearing the sound of broken glass in the kitchen) to assume that the hearer broke something in the kitchen.

$$
\begin{aligned}
& \text { A: Sjarit il-diktor mif mawju:d-ah } \\
& \text { Car of-doctor NEG exist-it } \\
& \text { 'The doctor's car is not here.' } \\
& \text { B: Jikil-uh il-diktor mif dzaj } \\
& \text { Shape-him ART-doctor NEG come } \\
& \text { 'Evidentially, the doctor is not coming.' }
\end{aligned}
$$

Speaker A tells speaker B that he did not see the car of the doctor, so B assumed that the doctor is absent. In this example, the speaker depends on inference as a source of information.

(6) Jikil-ik kayn-ah tibki

Shape-you be. Past-you.F cry

'Evidentially, you have been crying.'

The speaker in 6 sees that her friend's eyes are red, so she assumed that her friend has been crying. Thus, fikil is used to indicate a source of information. 
The word fikil also undergoes the process of decategorization. It is developed from a noun to serve the grammatical function of an evidential particle. It also loses its nominal features. As an evidential particle, it cannot accept determiners and cannot be pluralized, as shown from the following ill-formed structures:

$$
\begin{array}{lllrl}
\text { *al-fikil-na } & \text { rah } & \text { ni-ta?xar } & \text { San } & \text { il-dawam } \\
\text { ART-evidentially-we } & \text { future particle } & \text { we-late } & \text { to } & \text { ART-work } \\
\text { * ?fkalna: } & \text { rah } & \text { ni-ta?xar } & \text { San } & \text { il-dawam } \\
\text { Evidentially. P } & \text { future particle } & \text { we-late } & \text { to } & \text { ART-work }
\end{array}
$$

As it is shown in the previous examples, the evidential particle $/$ ikil cannot accept the definite article in 7 and cannot be pluralized in 8. This proves that fikil as an evidential particle loses the grammatical features of nouns.

Concerning the position of the noun fikil in utterances, it occurs initially, medially, and finally as a subject, object, or complement. Consider the following examples:

$$
\begin{array}{llc}
\text { Ma: } & \text { Juft } & \text { Jikil-uh } \\
\text { NEG } & \text { see. } 1 \text { S.G. } & \text { shape-GEN } \\
& \text { 'I did not see him' }
\end{array}
$$

In this example, fikil 'shape' comes finally as the complement of the verb / Juft/ 'see'.

$$
\begin{array}{lll}
\text { Jikil } & \text { il-saSah } & \text { darri: } \\
\text { Shape } & \text { ART-clock } & \text { circle }
\end{array}
$$

'The shape of the clock is a circle'

In 10, fikil 'shape' as a noun occurs initially as a subject of the clause.

However, it is unmarked that the evidential particle fikil occurs at the beginning of the utterance. The data showed that $70 \%$ of $/ i k i l$ tokens as an evidential particle occur initially. Thus, there is a change in the position of fikil when it is developed into a particle.

The last process of grammaticalization is the phonological reduction in which the particle $/$ ikil loses stress. Consider the following example:

$$
\begin{gathered}
\text { fikil maћal msakir } \\
\text { Evidentially, ART shop closed } \\
\text { 'Evidentially, the shop is closed' }
\end{gathered}
$$

In the previous example, the evidential particle $\int i k i l$ does not carry stress.

\subsection{Noun > negative polarity item:} examples:

The noun omir in Jordanian Arabic has the semantic meaning of "age", as shown in the following

$$
\begin{array}{llcl}
\text { Omir } & \text { Mohammad } & 20 & \text { sanah } \\
\text { Age } & \text { Mohammad } & 20 & \text { years }
\end{array}
$$

'Mohammed is 20 years old'

$$
\begin{aligned}
& \text { Kam omir-ak? } \\
& \quad \text { How age-you. M? } \\
& \text { 'How old are you?' }
\end{aligned}
$$

In Jordanian Arabic, omir 'age' underwent the process of grammaticalization. The first process is semantic bleaching in which it developed its original meaning as a noun meaning 'age' to indicate a negative polarity item. Negative polarity items (NPIs) refer to linguistic expressions that must occur in negative, conditional, or interrogative syntactic structures (Fauconnier, 1975; Ladusaw, 1979; Zwarts, 1981). Consider the following example:

$$
\begin{array}{rcccc}
\text { Omir-ak ma: } & \text { rah tindzah iða: ma: daras-at } \\
\text { Never-you } & \text { NEG will succeed if NEG study-you } \\
& \text { 'You will never succeed if you do not study' }
\end{array}
$$

It is clear from the previous examples that omir 'age' developed to serve as a polarity item 'never'.
Omir-i ma: fihimit
i-lrja:d dja:t 


Ever-I NEG understand ART-math
Mi:n omir-uh did not ever understand math'
Who ever-GEN simiS la Eminem ?
'Whoever listens to Eminem?' to Eminem

In examples 15 and 16, Omir was used in a negative structure and an interrogative structure functioning, respectively, as the negative polarity item 'ever'. It is worth noting that Jordanians used omir as a lexical meaning 'age' and as a negative polarity item.

Omir also undergoes the process of decategorization as it loses the syntactic and morphological features of nouns and is used as a negative polarity item that occurs in restrictive structures: negative, yesno question, and conditional constructions, as shown in the following examples:

$$
\begin{aligned}
& \text { Ma: omir-i sa:fart ila als } \mathrm{i} i \text { :n } \\
& \text { NEG ever-I travel. 1.S.G. to China } \\
& \text { 'I have never traveled to China' }
\end{aligned}
$$

$\begin{array}{llll}\text { Omir-ak ruht } & \text { ala il-sinema? } \\ \text { Ever-you } & \text { go. Past } & \text { to } & \text { ART-cinema? }\end{array}$

'Have you ever went to the cinema?'

$$
\begin{gathered}
\text { iða: omir-ak txabi: San-ha: rah Tiz̧al } \\
\text { If ever-you hide from-her will become angry. 3SG.F from-you }
\end{gathered}
$$

'If you ever keep anything from her, she will be angry with you'.

When the noun omir 'age' evolved into a negative polarity item, it lost the stress. The results of the study showed that the nouns fikil 'shape' and omir 'age' underwent the process of grammaticalization. Their development is in line with a chain or a cline of grammaticalization suggested by Hopper and Traugott (2003). Omir and fikil underwent the first stage of this path as they develop from lexical words into grammatical words. While / $\mathrm{ikil} /$ is developed into an evidential particle, omir developed into a negative polarity item. However, these words did not develop yet to a clitic or an affix. Besides, the development of these words agree with the stages of grammaticalization proposed by Bybee (2003), and Hopper and Traugott (2003). Both words underwent the processes of semantic bleaching, decategorization, and phonetic reduction. The results are in line with all the previous studies in the sense that content words evolved into grammatical words.

\section{Conclusion}

The present study aimed at investigating the grammaticalization of the nouns fikil 'shape' and omir 'age' in Jordanian Arabic. The analysis of the data showed that both nouns evolved from nouns to serve grammatical words through the process of grammaticalization. The findings showed that the noun fikil developed through the process of semantic bleaching into an evidential particle. Additionally, it loses the morphosyntactic features of a noun by the process of decategorization. At the final stage, fikil as an evidential particle lost stress. The findings also showed that the noun omir underwent the process of semantic bleaching, decategorization, and phonetic reduction. It evolved into a negative polarity item, lost the morphosyntactic features of a noun, and stress. The study also found out that Jordanians used fikil and omir as lexical items and as grammatical words in their utterances. The study recommends that researchers investigate the grammaticalization of omir and fikil in different Arabic vernacular dialects.

\section{REFERENCES:}

Al-Shawashreh, E., Jarrah, M \& Zuriakat, M. (2020)

Aikhenvald, Alexandra (2004)

Al-Najjar, Balkees. (1991)
The functions of grammaticalized verb to say in the Jordanian Arabic dialect of

Irbid. // Poznan Studies in Contemporary Linguistics, 3, p. 1-37

Evidentiality. New York: Oxford University Press, 25 p.

Grammaticalization of Lexical Markers in Kuwaiti Arabic. // Folia Linguistica 25, p. 665-674. 
Alotaibi, B (2016)

Alshboul, S., Y. Al-shaboul \& S. Asassfeh (2010)

Boas, Frans (1938)

Bybee, Joan, William

Pagliuca, and Revere

Perkins. (1991)

Bybee, Joan. (2003)

Camilleri, M. \& Sadler, L. (2017)

Eifan, E. (2017)

Fauconnier, Gilles (1975)

Haiman, John. (1991)

Heine, B. (2003)

Heine, B. \& M. Reh (1984)

Heine, B., U. Claudi \& F.

Hünnemeyer. (1991)

Heine, Bernd, and Heiko

Narrog, eds. (2011)

Hopper, P. J. and E. C.

Traugott. (2003)

Jarad, N.I. (2014)

Jarad, N. I. (2015)

Jarad, N. I. (2017)

Jarrah, M. and M.

Alshamari (2017)

Ladusaw, William A.

(1979)

Lehmann, C. (1995)

Traugott Elizabeth Closs,

Heine Bernd (eds.). (1991)

Traugott Elizabeth Closs,

Dasher Richard B. (2002)

Traugott, Elizabeth Closs, and Greame Trousdale

(2010)

Woidich, M. (1995)

Zwarts, Fr. (1981)
Multi-functional Verbs gaam \& gaSad in Kuwaiti Arabic: Between Serialization and Auxilation. 2nd Arabic Linguistics Forum Conference, held 12/12/201614/12/2016, York (p. 21-23)

Grammaticalization patterns: Evidence from future markers in Jordanian Arabic. // Journal of the Australasian Universities Language and Literature Association 114, p. 99-110.

Language.-In: Boas, F. General Anthropology.Boston, New York: D. C. Heath and Company, p. 124-45.

Back to the Future-In: Elizabeth Closs Traugott and Bernd Heine, Approaches to Grammaticalization. Amsterdam: John Benjamins, p. 17-58.

Mechanisms of Change in Grammaticalization: The Role of Frequency. In Richard Janda and Brian Joseph, Handbook of Historical Linguistics. Oxford: Blackwell, p. 602-623.

Posture Verbs and Aspect: A View from Vernacular Arabic. Proceedings of the LFG'17 Conference University of Konstanz Miriam Butt, Tracy Holloway King (Editors) 2017 CSLI Publications, p. 167-187.

Grammaticalization in Urban Hijazi Arabic. MA: The University of Manchester, $60 \mathrm{p}$.

Polarity and the Scale Principle, // CLS, 11, p. 188-199.

From V/2 to Subject Clitics: Evidence from Northern Italian-In: Elizabeth Closs Traugott, Bernd Heine (EDs.), Approaches to grammaticalization: Focus on theoretical and methodological issues. John Benjamins Publishing, p. 135-158. Grammaticalization- In: B. D. Joseph \& R. D. Janda (Eds.), The handbook of historical linguistics,. Oxford: Blackwell, p. 575-601.

Grammaticalization and reanalysis in African languages. Hamburg: Helmut Buske Verlag, 299 p.

Grammaticalization: A Conceptual Framework. Chicago / London: The University of Chicago Press, 327 p.

Introduction to The Oxford Handbook of Grammaticalization. Oxford: Oxford University Press, $456 \mathrm{p}$.

Grammaticalization. Cambridge: Cambridge University Press, 298 p.

The Grammaticalization of the motion verb "Rah" as a prospective aspect marker in Syrian Arabic. // Al- 'Arabiyya 47, p. 101-118.

From bodily posture to progressive aspect marker. // Lingua posnaniensis 56, p. 89-111.

Grammaticalization in Emirati Arabic. // Arabica 64, p. 742-760.

The syntax of the evidential particle Jikil in Jordanian Arabic. // Italian Journal of Linguistics 29, c. 29-56.

Polarity sensitivity as inherent scope relations. Doctoral Dissertation, University of Texas, $80 \mathrm{p}$.

Thoughts on grammaticalization. Munich: LINCOM-Europa, 183 p.

Approaches to Grammaticalization. Amsterdam: John Benjamins, 360 p.

Regularity in Semantic Change. Cambridge: Cambridge University Press, 341 p.

Introduction to Gradience, Gradualness and Grammaticalization, Philadelphia: John Benjamins, 306 p.

Some cases of grammaticalization in Egyptian Arabic, AIDA II Proceedings, p. 259-268.

Negatief polaire uitdrukkingen . // Glot 4, p. 35-132. 